\title{
Successful Treatment of Mesentric Panniculitis by Using Small Doses of Steroid for a Short Period: Case Report
}

\author{
Olla A M Ibrahim*, Salah M Alwamy and Enas M Alhaen \\ Department of Radiology, Faculty of Medicine, Omar Al Mukhtar University Al-Bayda, Libya
}

Received: 13 June 2019/ Accepted: 30 December 2019

Doi: https://doi.org/10.54172/mjsc.v34i4.198

\begin{abstract}
Mesenteric panniculitis is a rare inflammatory disease affecting the adipose tissue of the mesentery and colon. Less than 300 cases had been reported worldwide by 2016 . There is a lack of universal consensus regarding management guidelines, and the cases are treated on an individual basis. Therefore, successful management of this case by using small doses of steroid would empower clinician's experience of how to manage such cases. A 62-year-old female has a known case of hypertension and bronchial asthma, presented by exacerbation and acute abdominal pain. Lab results revealed a mild elevation in inflammatory markers and bilirubin. Computed tomography showed typical findings of mesenteric panniculitis. The case was managed by a small steroid dose for a short period till the symptoms were controlled, thereafter the dose was safely tapered gradually. A follow-up scan revealed complete resolution of the disease. The literature reports different types of therapy, ranging from observation to medical therapy and even surgical interventions. Reported cases were treated by different protocols using steroids, cytotoxic drugs, antibiotics and radiotherapy has been used in some cases, Reporting this case would raise awareness of how symptoms would present, what is the essential diagnostic tool to be used, and highlighting the possibility of using a small dose of steroid to successfully manage such cases.
\end{abstract}

Keywords: Mesentery; Panniculitis; Colon; Computed Tomography; Abdominal Pain; Acute Abdomen

\section{INTRODUCTION}

Mesenteric panniculitis is a rare inflammatory disease affecting the adipose tissue of the mesentery and colon, characterized by chronic nonspecific fibrotic inflammatory involvement of adipose tissue of the mesentery (Issa \& Baydoun, 2009). In 2016 less than 300 cases have been reported worldwide (Kgomo et al., 2017). Mesenteric panniculitis was first described by Jura in 1924 as retractile mesenteritis. The name mesenteric panniculitis was firstly given by Odgen 1960.

Although different names have been given for this disease in literature, such as mesenteric sclerosis, retractile mesenteritis, Weber-
Christian disease, lipomatosis, it can be categorized into three types according to the degrees of pathological changes in terms of inflammation, fat necrosis, and fibrosis (Nicholson et al., 2010).

Clinical presentation of the disease varies widely from nonspecific symptoms such as abdominal pain, nausea, anorexia, fullness, pyrexia; to more alarming presentations like acute abdomen, intestinal obstruction, jaundice, and per rectal bleeding (Issa \& Baydoun, 2009; Kgomo et al., 2017).

As this disease is quite rare, there is a lack of universal management guidelines, and cases are treated on an individual basis. In this case

*Corresponding Author: Olla A M Ibrahim dr_all2000@yahoo.com , Department of Radiology, Faculty of Medicine, Omar Al Mukthar University Al-Bayda, Libya . 
report, the clinical presentations and the diagnostic approach will be described. The management protocol and follow up will be illustrated in comparison with other published cases to raise awareness of this rare condition.

Case presentation: A 62 years old female Syrian patient was admitted to Al-Tamuz private hospital with two main complaints. The first is a 5 days abdominal pain, moderate to severe in intensity, mainly in epigastric and right hypochondrium regions, continues, colicky, burning in nature, poorly radiates to the rest of the abdomen; associated with nausea, vomiting, low-grade fever. No change in bowel habits. There is a history of multiple similar episodes, but they were less in intensity.

The second complaint is a mild productive cough associated with a wheezy chest. Her past medical history included hypertension for 10 years on Atenolol 100mg/day. Bronchial asthma on bronchodilator inhaler. Asthmatic attack precipitated by dust and cold exposure.

The past surgical history included classic cholecystectomy 3years ago. No known history of allergy, apart from the precipitating factors for asthma.

Clinical examination revealed: overweight patient, vitally stable, temperature $38 \mathrm{c}^{\circ}$, mild jaundice, and congested throat.

Local examination of the chest revealed a bilateral occasional expiratory wheeze.

Adnominal examination showed moderate to severe tenderness over epigastric and right upper quadrant regions, rebound was positive, bowel sound was positive.

Lab results: leukocyte counts $13 \times 10^{\prime 3}$, total Bilirubin $2.4 \mathrm{mg} / \mathrm{dl}$, mainly direct, mild elevation in liver enzymes, sedimentation rate 60 $\mathrm{mm}$ /one hour, $\mathrm{C}$-reactive protein positive.
Renal function, the rest of liver function, serum amylase, urine amylase, cardiac enzymes, and coagulation profile were all within normal ranges.

ECG: showed no significant abnormality. Chest x-Ray: bi-lateral mild perihilar infiltration.

Abdominal ultrasound examination demonstrated a thick gastric wall with an increase in fluid content. Surgically removed gall bladder, mild fatty liver changes, and otherwise normal findings.

CT of the Abdomen performed initially without contrast, followed by intravenous contrast injection (figure-1).

Revealed veil-like opacity radiating from the mesenteric root, which is extending peripherally, and more prominent around jejunum, with sandstorm appearance. An increase in the thickness of the stomach wall and small intestine are highly suggestive of mesenteric panniculitis. 


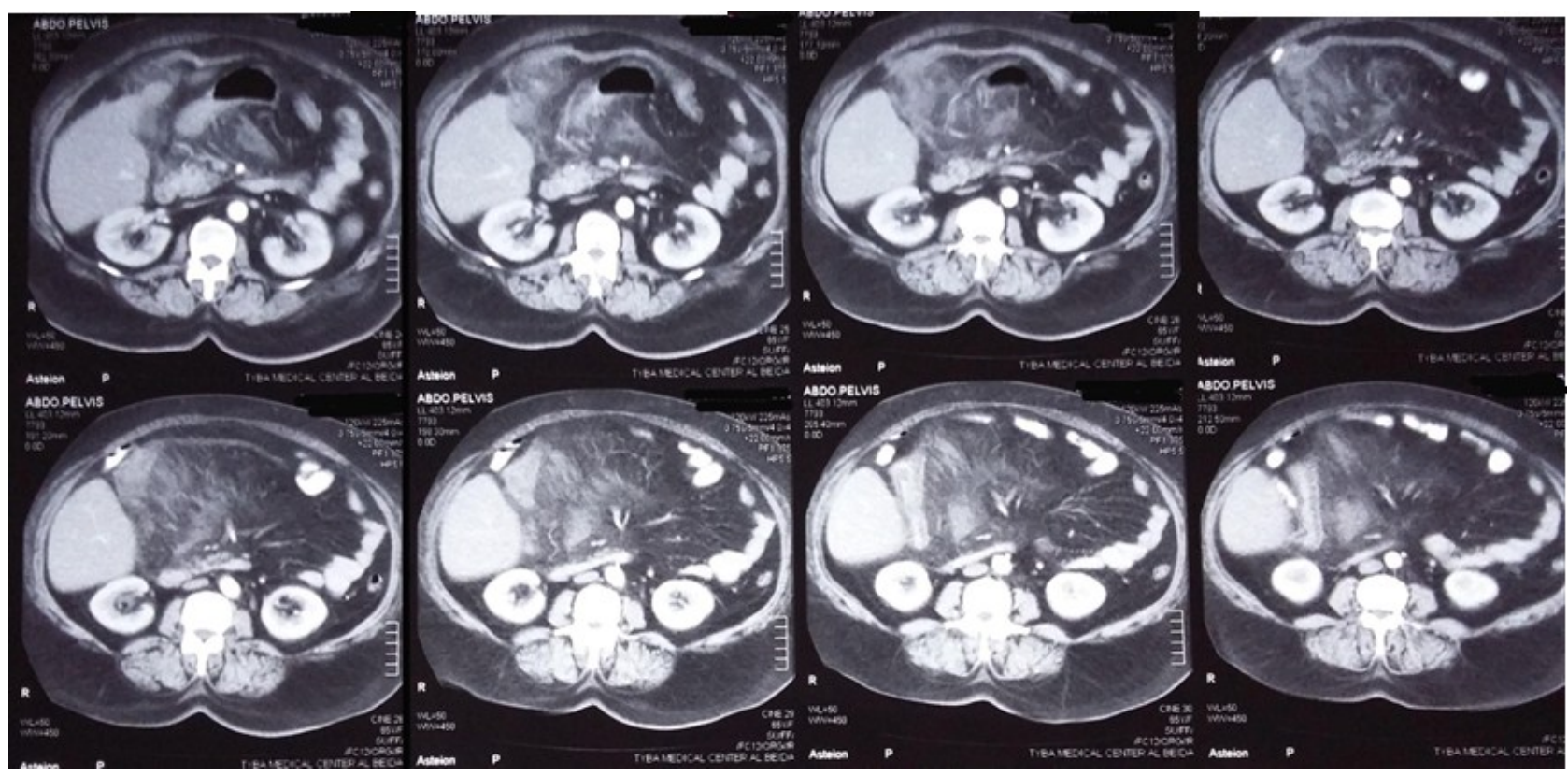

Figure (1): Abdominal and pelvic CT scan with contrast showing sandstorm appearance of mesenteric panniculitis (cross sectional view).

Management and Outcome: Patient was treated by $30 \mathrm{mg}$ prednisone once daily, bilirubin repeated after two days of therapy and returned to normal value, and the pain significantly reduced. The patient discharged home with the same dose until the pain almost subsided. On week 2 post-presentation, the dose was reduced to $20 \mathrm{mg} /$ day for another two weeks and then tapered over one month. The Patient underwent follow up CT after two months of presentation.

The second CT showed a complete resolution of pathology (figure-2). The patient followed for 6months, and the patient was symptoms free during the follow-up period.

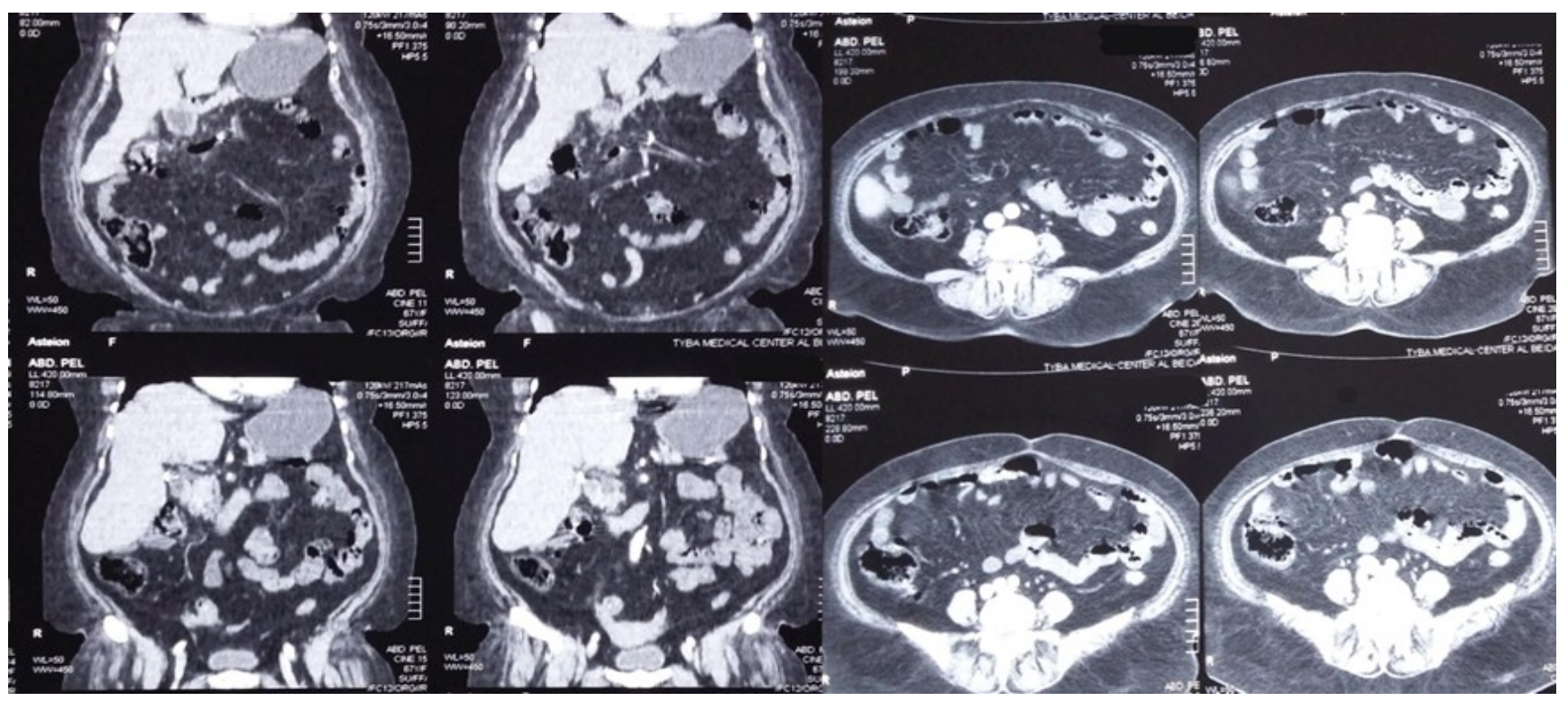

Figure (2): Abdominal pelvic CT scan with contrast showing resolution of mesenteric panniculitis (coronal and crosssectional views). 


\section{DISCUSSION}

Mesenteric panniculitis is a fibrotic inflammatory disease that involves the adipose tissue of mesentery. By 2016, Less than 300 cases had been reported in literature under different names: mesenteric lipomatosis, lipogranuloma of mesentery, retractile mesenteritis and other names (Grieser et al., 2008; Issa \& Baydoun, 2009).

This disease is more common in males with 2$3: 1$ ration, incidence increases with age (Irwin et al., 2018).

The precise etiology is not fully understood. However, the pathogenesis of this disease is thought to be a nonspecific inflammatory response linked to a wide variety of stimuli. For example, abdominal trauma, surgery, autoimmune related disorders, chemical injuries, drugs, retained intra-abdominal materials, leakage into the abdominal cavity (urine, bile, chyle), peptic ulcer and even tobacco consumption has been reported to increase the risk (Irwin et al., 2018; Issa \& Baydoun, 2009; Kaya et al., 2018). In addition, the retractile form of mesenteric panniculitis is associated with some types of Malignancies, such as lung cancer, lymphoma, melanoma, gastric cancer, carcinoid tumor (Cuff et al., 2001; Irwin et al., 2018; Kaya et al., 2018; Kgomo et al., 2017). In our case, no clear causal factors can be linked, and cholecystectomy was done 3 years earlier, makes surgical procedure unlikely to be related here. The most common site is mesenteric of small bowels, However, mesenteric of sigmoid, mesocolon, peri-pancreatic region, omentum, retroperitoneum, and pelvic involvement had been reported (Akram et al., 2007; Horton et al., 2003). In our case, small bowels' mesentery and part of the omentum were the main sites of involvement.

The mode of presentation widely ranges from asymptomatic, mild symptoms to a picture of an acute abdomen. The symptoms might include: abdominal pain, pyrexia, anorexia, nausea, weight loss, abdominal fullness, and less occasionally, the patient might present with jaundice, anemia, per rectal bleeding, abdominal mass and intestinal obstruction (Kgomo et al., 2017; Pickhardt \& Bhalla, 2005). In this case, the patient is present with abdominal pain similar to acute abdomen, in addition to jaundice, which can be explained by edematous of peri-biliary tree tissues as a part of mesenteric inflammation and subsided after administration of prednisone.

Diagnosis of the disease is mainly achieved by the usage of computerized tomography, and Magnetic resonance imaging. The definitive diagnosis is reached by biopsy, which is seldom required unless there is doubt in regarding diagnosis (Horton et al., 2003; Pickhardt \& Bhalla, 2005). In this case, CT was enough to make a diagnosis and the close follow up with improvement in symptoms minimize the need for biopsy.

The laboratory results usually tend to be within normal ranges, apart from elevated neutrophils, raised sedimentation rate, and occasionally, anemia (Kaya et al., 2018). Our case shows almost the same biochemistry of the majority of cases, in addition, an increase in total bilirubin, mainly direct type, this might be explained by the edematous biliary tree due to the extension of inflammation of omentum that relived after administration of prednisone.

As with most rare diseases, there is a lack of universal consensus regarding management guidelines, and the cases are treated on an individual basis. Literature reports different types of therapy, ranging from observation to medical therapy and even surgical interventions. In general, medical therapy is used for symptomatic cases. The usual medications are, steroids, thalidomide, cyclophosphamide, colchicine, azathioprine, tamoxifen, antibiotics, and radiotherapy has been used in some cases, while surgical intervention is usually served if medical treatment had failed (Issa \& Baydoun, 2009; Kaya et al., 2018). 
As our patient is symptomatic, Prednisone was the main medication for this case, $30 \mathrm{mg}$ was used for two weeks, and as the pain subsided, $20 \mathrm{mg}$ started for almost another two weeks, then tapered over one month. In comparison to (Issa \& Baydoun, 2009; Kgomo et al., 2017), we have used a smaller dose of prednisone $30 \mathrm{mg}$ instead of $40 \mathrm{mg}$, and for only 2 months with tapering approach instead of six months in the former and a little longer than that of the later, where (Kgomo et al., 2017) used a small dose for two weeks, and tapering of steroid was omitted, which might jeopardize the health status of their patient. Antibiotics (cephalosporins) have been used for 5days as part of the management of bronchial asthma exacerbation, not as an intention for curing panniculitis.

\section{CONCLUSION}

Mesenteric panniculitis is a rare disease, with variable clinical presentations, mostly it is a benign condition. However, it can be presented as a secondary manifestation of some malignancies. There is no universal consensus regarding treatment guidelines. Hopefully, improving doctors' knowledge would raise awareness of how such a case would present, what essential diagnostic tool to be used, and that a small dose of a steroid with good followup would be effective management rather than a larger dose over a longer time frame.

\section{Abbreviation}

CT: Computerized tomography.

\section{REFERENCES}

Akram, S., Pardi, D. S., Schaffner, J. A., \& Smyrk, T. C. (2007). Sclerosing mesenteritis: clinical features, treatment, and outcome in ninety-two patients. Clinical Gastroenterology and Hepatology, 5(5), 589-596.

Cuff, R., Landercasper, J., \& Schlack, S. (2001). Sclerosing mesenteritis. Surgery, 129(4), 509-510.
Grieser, C., Denecke, T., Langrehr, J., Hamm, B., \& Lopez Hänninen, E. (2008). Sclerosing mesenteritis as a rare cause of upper abdominal pain and digestive disorders. Acta Radiologica, 49(7), 744746.

Horton, K. M., Lawler, L. P., \& Fishman, E. K. (2003). CT findings in sclerosing mesenteritis (panniculitis): spectrum of disease. Radiographics, 23(6), 15611567.

Irwin, C. P., Lee, J. B., Kim, A., Eme, I., Schofield, C., \& Mount, G. (2018). Mesenteric panniculitis presenting as fever of unknown etiology in a patient with history of abdominal surgery. Case reports in gastrointestinal medicine, 2018.

Issa, I., \& Baydoun, H. (2009). Mesenteric panniculitis: various presentations and treatment regimens. World journal of gastroenterology: WJG, 15(30), 3827.

Kaya, C., Bozkurt, E., Yazıcı, P., İdiz, U. O., Tanal, M., \& Mihmanl1, M. (2018). Approach to the diagnosis and treatment of mesenteric panniculitis from the surgical point of view. Turkish journal of surgery, 34(2), 121.

Kgomo, M., Elnagar, A., \& Mashoshoe, K. (2017). Mesenteric panniculitis. Case Reports, 2017, bcr-2017-220910.

Nicholson, J., Smith, D., Diab, M., \& Scott, M. (2010). Mesenteric panniculitis in Merseyside: a case series and a review of the literature. The Annals of The Royal College of Surgeons of England, 92(6), e31-e34.

Pickhardt, P. J., \& Bhalla, S. (2005). Unusual nonneoplastic peritoneal and subperitoneal conditions: CT findings. Radiographics, 25(3), 719-730. 


\title{
تقرير عن حالة نجاح علاج التهاب السنبلة الشحمية المساريقي باستخدام جرعة صغيرة من الستيرويد ولفترة قصيرة
}

\author{
علا عبد الرحمن محمد إبراهيم "، صلاح مفتاح العوامي وإيناس مصطفى الهاين

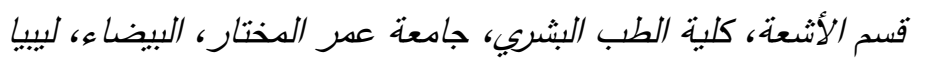

تاريخ الاستلام: 13 يونيو 2019 / تاريخ القبول: 30 ديسمبر 2019 https://doi.org/10.54172/mjsc.v34i4.198:Doi

المستخلص: التهاب السبلة الثحمية المساريقية هو مرض التهابي نادر يؤنثر على الأنسجة الدهنية للمساريق والقولون. أقل من

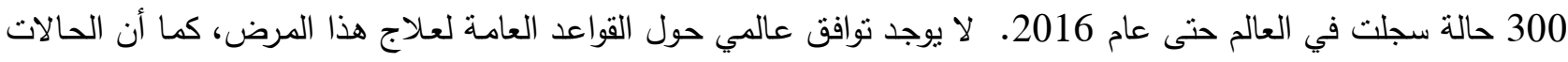
المسجلة نم علاجها بصورة فردية. لذلك فان نجاح علاج هذه الحالة بجرعات صغيرة من العقار الكورثيزوني من شانه إثراء الخبرة السريرية للأطباء في كيفية التعامل مـع حالات مماتلةة. التقرير يُعني بحالة سيدة تبلغ من العمر 62 سنة وتعاني من ارتفاع

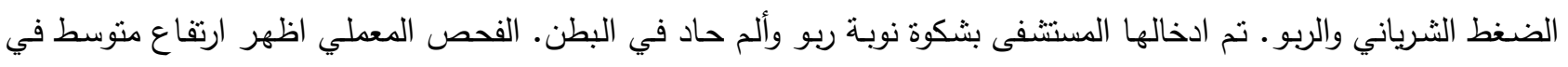
مؤشرات الالتهابات وكذلك البليروبين (الصفراء). الصورة المقطعية اظهرت النمط النموذجي لالتهاب السبلة الثحمية المساريقية. عُلجت الحالة باستخدام جرعات صغيرة من الكورتيزون لفترة قصيرة حتى زوال الاعراض المرضية، ومن ثم ايقافها بشكل تدريجي

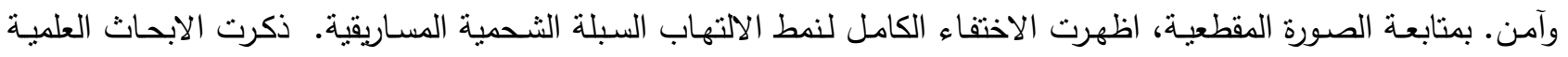
المنشورة طرق علاج مختلفة لهذه الحالة تتباين من مجرد الملاحظة والمتابعة إلى استخدام العقارات الطبية والتدخلات الجراحية. سُجلت حالات شفاء باستخدام بروتوكولات علاجية مختلفة باستخدام الكورتيزون، ومضادات الأورام، والمضادات الحيوية والعلاج

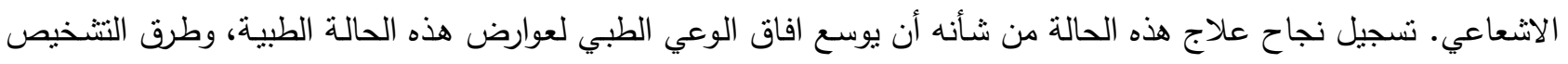
الأساسية لها ويسلط الضوء على أن استعمال جرعات صغيرة من العلاج الكوتيزوني ممكن ان يكون خيار فعال لهذه الحالات. الكلمات المفتاحية: مساريقي، التهاب السنبلة الثحمية، القولون، الصورة المقطعية، ألم البطن، البطن الحادة. 